\title{
Životna priča jednog iseljenika kao izvor za proučavanje migracija
}

DOI: https://doi.org/10.11567/met.33.2.5

\section{Sanja Lazanin}

Institut za migracije i narodnosti, Zagreb

sanja.lazanin@imin.hr

Knjiga Tužna povijes moga života: dnevnički zapisi koju je objavila Matica hrvatska - Ogranak u Dubrovniku 2017., a uredila Marina Vicelja-Matijašić, sadržava zapise osobne naravi o iseljeničkom iskustvu Vicka Njirića - Puhe, Zatonjanina koji se krajem 19. i početkom 20. stoljeća odselio u Južnu Ameriku u potrazi za poslom i boljim životom. Knjigu su za objavu priredili Njirićevi potomci (prof. dr. sc. Marina Vicelja-Matijašić i Antun Tonko Lonza), a ona je na promociji u Dubrovniku izazvala velik interes. Razumljivo je da tekst koji sadržava podatke iz autorova osobnog života i reference na brojne osobe, kako iz autorova zavičaja tako i na one iseljene u Južnu Ameriku, može izazvati zanimanje autorovih rođaka i lokalnog stanovništva u želji da nadopune svoja sjećanja i znanja o precima. No kako i zašto ta knjiga, osim kao zanimljivo štivo, može biti korisna povjesničarima i istraživačima različitih struka koji se bave prekomorskim migracijama, osobito zato što je riječ o tekstu u kojemu se izlažu autorov osobni život i njegov pogled na svijet i događaje?

O važnosti takvih tekstova za povijesna istraživanja, prije svega u kontekstu intelektualne, kulturne i društvene povijesti, pisao je njemački povjesničar Richard van Dülmen. Opisujući u svom djelu Otkriće individuuma oblike samotematiziranja $\mathrm{u}$ ranome novom vijeku, autor navodi poticaje i razloge za nastanak takvih zapisa. Kao primarni povod pisanju autobiografije van Dülmen naglašava potrebu da se ostavi poruka za obitelj i potomstvo, što je osobito bilo naglašeno u 16. i 17. stoljeću. Također ističe želju pojedinca za ovjekovječenošću, potrebu za opravdanjem vlastitih postupaka ili nastojanje da se ostavi jasnija slika o sebi - o svojim mislima, osjećajima, stavovima i postupcima; drugim riječima, potrebu za autorefleksijom.

Među poznatijim tekstovima osobne naravi, koji su nastali tijekom ranoga novog vijeka i koji su, prema van Dülmenu, bili izraz procesa emancipacije pojedinca i građanstva u nastajanju, bile su različite autobiografije, dnevnici i pisma. Van Dülmen ističe neke povijesno zanimljive autobiografije koje su po mnogočemu bile inovativne ili su poslužile kao uzor drugima. To su, da 
navedemo samo nekoliko najpoznatijih, autobiografija firentinskog zlatara Benvenuta Cellinija (16. st.), zatim kölnskog pravnika Hermanna von Weinsberga, pariškog nadbiskupa i pripadnika plemićke fronde Jeana Françoisa de Retza (17. st.), engleskog puritanskog propovjednika Johna Bunyana (17. st.), Jean-Jacquesa Rousseaua i Johanna Wolfganga Goethea. Osim toga van Dülmen navodi i neke istraživački zanimljive ranonovovjekovne dnevnike, primjerice dnevnik nepoznatoga pariškoga građanina iz 15. st., dnevnik osnivača Isusovačkog reda Ignacija Loyole, dnevnik engleskog astrologa i matematičara Johna Deeja iz 16. st. - prvi takav dokument koji izvještava i o intimnom životu, zatim poznati The Diary tajnika britanskog admiraliteta Samuela Pepysa iz 17. st., kao i primjere nekih drugih, manje ili više slavnih autora tekstova osobne naravi.

Nakon ove kratke povijesne perspektive o autoreferencijalnim tekstovima opravdano je zapitati se u koju bismo kategoriju tekstova osobne naravi mogli svrstati zapis o vlastitu životu »conpanera iz Zatona«. Što je tog težaka i običnog radnika, koji je kao mladić krajem 19. stoljeća krenuo u Ameriku u potragu za boljim životom, potaknulo na zapisivanje pojedinosti iz vlastitog života te kako takav tekst, osim članovima obitelji i nasljednicima, može poslužiti općenito kao povijesni izvor i kao izvor za proučavanje iseljeništva? Neke odgovore na ta pitanja možemo pronaći i u samom tekstu Vicka Njirića zvanog Puho iz Zatona, a neke je potrebno potražiti posredno, uzimajući u obzir teorijska promišljanja i istraživanja različitih humanističkih disciplina.

Kad je riječ o pisanim povijesnim izvorima, posebno mjesto među njima zauzimaju oni zapisi koji se podvode pod pojam tradicije, a to su svi oni tekstovi koji su nastali s namjerom da se potomstvu i općenito budućim naraštajima ostavi obavijest o određenim događajima, bez obzira na način na koji su se doista dogodili. U tu vrstu izvora ubrajaju se dnevnici, autobiografije, memoari, putopisi, anali, kronike, bajke, priče, zvučni i slikovni zapisi te slični dokumenti. Od navedenih, u postojećem kontekstu pozornost nam osobito privlače tzv. ego-dokumenti. Naziv je 1958. uveo nizozemski povjesničar i pisac Jacques Presser kako bi jednim pojmom obuhvatio sve one zapise koji sadržavaju svjedočanstva osobne naravi. Takva svjedočanstva mogu primjerice poprimiti oblik autobiografije, dnevnika, pisma, ali i isprave koja nije nastala dobrovoljnim aktom pojedinca, a ipak sadržava podatke osobne naravi, poput zapisa sa sudskih ispitivanja, raznih očitovanja u okviru administrativnih i gospodarskih procesa i sličnih vrsta izvora. Od razdoblja renesanse, s »otkrićem individuuma «, te općenito s porastom broja pismenih osoba rastao je broj ego-dokumenata, a porast broja autobi- 
ografija i memoara od 16. stoljeća usko je povezan s razvojem književnosti na narodnim jezicima.

U slučaju zapisa Vicka Njirića teško je jednoznačno žanrovski odrediti tu vrstu dokumenta, iako podnaslov objavljene knjižice sugerira da je riječ o vrsti dnevnika. Je li riječ o dnevniku, autobiografiji, memoarima ili o tekstu s elementima svega navedenoga? Iako, sudeći po stilu i sadržaju zapisa, autor nije imao nikakve književne aspiracije, nego samo elementarno pučkoškolsko obrazovanje, to nimalo ne umanjuje vrijednost njegovih zapisa - i kao autobiografskog teksta i kao povijesnog izvora.

Kako bi se žanrovski klasificirao Njirićev tekst, koji u prijepisu obuhvaća sedamdesetak tiskanih stranica pisanih idiomom zatonskog kraja ranog 20. stoljeća, potrebno je ukratko se osvrnuti na sličnosti i razlike pojedinih vrsta tekstova osobne naravi čiji se elementi mogu uočiti u zapisu koji je pred nama. Ne ulazeći u književnoteorijske rasprave o tome postoji li uopće žanr autobiografije ili je točnije govoriti o »autobiografskom ugovoru « (kako je to još sedamdesetih godina 20. stoljeća sugerirao francuski teoretičar Philippe Lejeune), osvrnimo se na historiografske aspekte teksta.

Povjesničari, kako kaže Jörg Engelbrecht, svrstavaju autobiografije i memoare $\mathrm{u}$ izvore osobne naravi koji su u bliskoj vezi s dnevnicima, pismima i izvještajima suvremenika. U historiografiji se pri definiranju takvih izvora ističe autorov odnos prema događajima o kojima izvještava. U slučaju zapisa Vicka Njirića jasno je da su autor i glavni »junak « teksta ista osoba. To nam i autor na samom početku teksta sugerira riječima »napisao svoj život tužni od godine 1889. do godine 1918.«.

Važan aspekt izvora osobne naravi jest i njihova neposrednost. U njima autor kao sudionik događaja, što je u slučaju Vicka Njirića nesporno, izravno svjedoči o doživljenome, dajući tom svjedočanstvu određenu vrstu autentičnosti koju očekujemo od neposrednog sudionika zbivanja. Doista, tko bi mogao neposrednije izvijestiti o nekom događaju ili o nečijem životu od samog njegova protagonista? Ipak, autentičnost nije isto što i vjerodostojnost, stoga je i ovome, kao i svakome drugom takvu tekstu, potrebno pristupiti s određenom dozom opreza i kritičkog odmaka. Već same bilješke kojima su priređivači opremili prijepis Njirićeva rukopisa upućuje na to da i neke jednostavne činjenice, poput datuma vjenčanja ili imena osoba, podliježu sumnji i provjeri. Povjesničari često upozoravaju na opasnost od nekritičke upotrebe podataka navedenih u takvoj vrsti izvora, ako ni zbog čega drugog, onda zbog varljivosti i pristranosti sjećanja. Stoga je prilikom evaluacije takvih izvora potrebno voditi računa o tome da izneseni vrijednosni stavovi o ljudima i događajima odražavaju, u većoj ili manjoj mjeri, 
autorove osobne poglede, predrasude i motive. Dakle kad je posrijedi vjerodostojnost autobiografskih i sličnih tekstova kao povijesnih izvora, jasno je da svaki izvještaj valja uzeti oprezno. No vjerodostojnost nije jedina njihova potencijalna vrijednost - takav izvor može biti koristan i kao svjedočanstvo o predodžbama, nazorima, osjećajima i težnjama tipičnim za određene kategorije stanovništva, određeni prostor i određeni povijesni trenutak. Drugim riječima, izvori osobne naravi važna su nadopuna drugoj vrsti izvora o prošlim događajima - onima koji su primarno fokusirani na same činjenice i njihov uzročno-posljedični slijed.

O nepostojanju jedinstvene definicije autobiografije svjedoče i riječi američkog teoretičara Jamesa Olneya (prema: Zlatar, 2000: 34): »Svi misle da znaju što je autobiografija ali se ni dvoje ljudi ne može složiti što doista ona jest.«Budući da se autobiografski i memoarski tekstovi žanrovski jasno razdvajaju tek u 18. stoljeću, to razgraničenje nije lako provesti ni kada su posrijedi tekstovi kasnijih razdoblja, kao što je slučaj i s našim zapisom. Ipak, neka distinktivna obilježja mogu biti od pomoći. Memoari su fokusirani na javni život osobe, obično se bave točno definiranim životnim razdobljem, najčešće autorovim javnim djelovanjem, namijenjeni su za objavu, a često izražavaju i autorove historiografske ambicije. Neke od tih značajki mogu se uočiti i u Njirićevu tekstu.

Zapis Vicka Njirića sadržava vremenske odrednice događaja koje opisuje. Premda nema jasnih indicija da je njegov životopis bio namijenjen objavljivanju, autor na samom kraju u »Opazki« prešutno izražava očekivanje da će njegov tekst imati publiku: »Molim, svi oni koji budu štili ovu moju tužnu poviest moga života da mi oproste, jer niesam imao nego samo pučku školu.«

Jasnom određenju karaktera nekog izvornog teksta osobne prirode često ne pomaže ni terminologija upotrijebljena u samom naslovu teksta. Tekst naslovljen kao »memoarski« može sadržavati i elemente autobiografije, i obratno, a najčešći su oni tekstovi u kojima su elementi dvaju žanrova pomiješani. S idealnotipskog stajališta razlika memoara i autobiografije leži ponajviše $u$ tome što memoari prikazuju postupanje pojedinca kao nositelja određene društvene funkcije, dok se u autobiografiji opisuju život pojedinca, njegova socijalizacija, odrastanje, obrazovanje i uključivanje u društvo. Također, autobiografija i memoari iz različitih perspektiva promatraju događaje o kojima izvještavaju. Dok u autobiografiji autor slijedi vlastite preferencije i piše o onome što ga najviše zanima, dotle su teme sastavljača memoara uvjetovane funkcijom i vrstom posla te odnosom prema drugim 
sudionicima opisanih događaja. Njegovi se motivi razlikuju od motiva pisca autobiografije. Memoari se pišu s ciljem tumačenja i prenošenja javnosti vlastitih pogleda na određene događaje, pri čemu autor vlastitu ulogu tipično nastoji prikazati u povoljnom svjetlu. Upravo to je razlog da se pisce memoara često sumnjiči za »izvrtanje povijesti«. Premda ni pisac autobiografije nije uvijek lišen takve sumnje, njegovu se izvještavanju obično pripisuje veća vjerodostojnost jer je predmet njegova opisa privatni život, a ne njegova društvena uloga. Drugim riječima, autor autobiografije podnosi račun o svom životu, radi sebe, iako s uvjerenjem da bi to što ima izvijestiti moglo zanimati i druge.

Prema riječima priređivačâ, izvorni tekst na temelju kojega je nastala Njirićeva Tužna povijes moga života bio je daleko opsežniji i u formi dnevnika, no ti su zapisi uništeni. Autor je, očito vođen željom da njegov buran i događajima bremenit život ne potone potpuno u zaborav, odlučio »sažeti« svoja sjećanja na iseljenički dio svog života i njegove »posljedice« te ih kronološki izložiti.

Dnevnik može imati različite oblike, sadržaje i funkcije, no njegovi su najvažniji konstitutivni elementi sukcesivno pripovijedanje, jasno razdvajanje pripovjednih cjelina i kronološka struktura. Vremenska je dimenzija dakle izuzetno važna za dnevnik, a od autobiografije ga razlikuje upravo to što ne postoji velika vremenska distanca između vremena pripovijedanja i vremena kad su se događaji odigrali, iako pripovijedanje može biti isprekidano dužim stankama. Nasuprot tome autobiografija je tipično obilježena vremenskom distancom u odnosu na događaje. Pritom nije rijedak slučaj da sama ta distanca, tj. u međuvremenu nakupljeno iskustvo, utječe na tumačenje pojedinih događaja - za razliku od dnevničkih zapisa, koji bilježe »neprerađeni« doživljaj. Nadalje, dnevnik obično nije namijenjen primatelju (ili mu barem to nije inicijalna funkcija), ne računa na sugovornika ili na javnost, pa zbog toga njegovi zapisi nisu uvijek i svima razumljivi. Poznati primjer dnevnika, koji prvotno nije bio namijenjen za objavu, jest Dnevniks puta u Italiju preko Švicarske i Njemačke 1580. i 1581. slavnog francuskog filozofa i začetnika esejističkog žanra Michela de Montaignea. Rukopis njegova dnevnika pronađen je nakon gotovo dva stoljeća te objavom izvučen iz zaborava. Dakako, postoje i slučajevi kada ni autobiografija nije namijenjena za čitanje drugima, ali oni su rijetki.

Njirićev tekst ima karakteristike svih triju samotematizirajućih zapisa autobiografije, dnevnika i memoara. Očito je da je nakon fizičke propasti prvotnoga, izrazito opsežnoga dnevničkog zapisa autorovo "pisanje o svom 
životu « promijenilo oblik, opseg, način i karakter te da je autorova namjera da ostavi trag o svom »tužnom životu « u konačnici poprimila formu koja je bliža autobiografiji nego dnevniku.

Ako bi se na autobiografiju gledalo kao na pokušaj »historizacije osobne povijesti« (izraz Andree Zlatar), kao na refleksiju o samome sebi, o svom životu i razvitku vlastite osobnosti, tada je možemo svrstati među povijesne izvore koji nam na najizravniji mogući način svjedoče o nekom vremenu i o duhu tog vremena. Svojim zapisima Vicko Njirić otkriva nam svoj životni put učenja i migrantskog iskustva u Argentini i Čileu, koji je bio obilježen brojnim poteškoćama (nesnalaženjem, upućenošću na zemljake, malom zaradom, teškim uvjetima rada i bolešću), ali koji je polučio određene uspjehe (povratak u zavičaj s ušteđevinom, društvena afirmacija, odricanje od nasljedstva, postizanje ekonomske neovisnosti i zasnivanje vlastite obitelji). Svoju životnu pouku pretače u sljedeće riječi: »A ja sada kada sam svega prošo i pretrpio na ovome lažnome svietu, da je dobro poštovati svakoga svoga, oca i majku, i sve svoje, ali vazda poštovati sama sebe više nego ikoga drugoga, pa ćeš sigurno biti sretan i na ovom i na drugom svijetu." Njegovi zapisi kao da su izraz te potrebe za samoafirmacijom, ali i potrebe da se nekomu ispovjedi, olakša tereta koji su ga tištali. Budući da je pouzdanje u crkvene dušobrižnike izgubio, a da u svoju neposrednu okolinu nije imao previše povjerenja, autobiografska forma vjerojatno se Vicku Njiriću ukazala kao idealan način da tu potrebu zadovolji.

Od ranoga novog vijeka, a osobito od kraja 18. stoljeća, oslobađajući karakter autobiografije bio je jedan od načina, ali i poticaja, za sve veći broj pismenih pojedinaca da se bave samima sobom. Činom opisivanja vlastitog života pojedinac je mogao »olakšati dušu «, osloboditi se pritiska društva, obitelji i crkve te tražiti razumijevanje potencijalnog čitatelja za »nepravde«, kao što je to učinio i autor zapisa iz Zatona. Ustvari, njegovoj se potrebi za »olakšanjem duše« to manje čudimo što više detalja saznajemo o njegovim obiteljskim prilikama - o odsutnosti razumijevanja za njegove nevolje od onih od kojih je to najviše očekivao: od roditelja, rodbine, Crkve i svoje neposredne okoline. Ujedno svjestan toga da bi njegove riječi mogle povrijediti upravo one koji su mu najbliži, Njirić daje čitateljima do znanja da je »cenzurirao« svoj zapis: »I kako sam uzrujan zbog nepravednosti, tako sam uzeo pod usta više osoba, gospara i popova. A i još bi više ali ne smiem pravo govoriti ni pisati.«

Dva se razloga ističu zbog kojih bi Njirićev autobiografski zapis mogao biti zanimljiv kao povijesni izvor. $S$ jedne strane, to o čemu izvještava samo je po sebi zanimljivo - njegova sjećanja na dogodovštine s putovanja drago- 
cjeno su svjedočanstvo o hrvatskoj ekonomskoj migraciji u Južnoj Americi na prijelazu iz 19. u 20. stoljeće, a njegovi opisi obiteljskih (ne)prilika otkrivaju neke društveno-ekonomske i kulturne obrasce toga vremena. $S$ druge strane, čitateljevu pozornost privlači i to kako izvještava. Njegov način pripovijedanja izrazito je osoban: objektivan opis događaja potpuno je podređen subjektivnoj perspektivi protagonista. To pogotovo dolazi do izražaja u dijelovima teksta u kojima govori o obiteljskim prilikama, razdiobi baštine i ekonomskom iskorištavanju od uže i šire rodbine. Na tim je mjestima ogorčenost i osjećaj iskorištenosti prevladavajuće raspoloženje, koje autor i ne pokušava sakriti. Unatoč toj naglašeno subjektivnoj perspektivi Njirićevi opisi ipak pružaju zanimljiv uvid u međuljudske odnose u različitim sredinama (koje često uspoređuje) te širi društvenokulturni kontekst u kojemu se kao radnik, migrant ili član obitelji zatekao.

Njirićev bi se tekst po temama kojima se bavi, po društvenom statusu svoga autora, ali i vremenu u kojem je nastao mogao dovesti u vezu s korpusom tekstova $\mathrm{tzv}$. »radničke literature«. Tu se prije svega misli na tekstove, uključujući one autobiografskog sadržaja, koje su pisali radnici, seljaci i uopće pripadnici nižih društvenih slojeva, a koji su nastali pod utjecajem poznatih književnih uzora. Načinom na koji su napisani ti tekstovi ponekad ostavljaju dojam da su djelo nadarenog pisca, a ne »običnog radnika«. Zbog toga je čest prigovor takvoj literaturi da nije autentična jer autori - čak i oni očito manje nadareni - pribjegavaju »usiljenom « načinu izražavanja koji ne odgovara govornom jeziku njihova društvenog sloja.

Kod Njirića upravo to nije slučaj jer u njegovu tekstu nema ni traga usiljenom načinu izražavanja $\mathrm{i} »$ literarizaciji« izričaja. To nije čudno jer vjerojatno nije ni imao nikakve književne uzore. Ta činjenica međutim ne umanjuje dokumentarnu vrijednost njegova teksta. Izričaj mu je najčešće sažet, bez nepotrebnih opisa, gotovo telegrafski, ali ostavlja dojam autentičnosti upravo zbog jezika. Njegov koncizan stil posebice dolazi do izražaja u opisu nekih povijesnih događaja poput nemira »rebolucionara « i zbacivanja Vlade u Argentini 1890. Jezgrovito izvješćujući o događajima i njihovim sudionicima, nadopunjujući ih često vlastitim dojmovima, Njirić upotrebljava govorni jezik kojim se vjerojatno i inače služio. Stoga je jezik zapisa ujedno vrijedno svjedočanstvo o lokalnom govoru Zatonu na prijelazu iz 19. u 20. stoljeće, osobito na primjerima toponimskih lokalizama, tj. geografskih naziva prilagođenih lokalnom govoru - Bonzaer (Buenos Aires), Chilenica, Uropa, Arđentina, Inglez, Amerikanica, Portugez i sl. - ili na primjerima tuđica prilagođenih lokalnom dijalektu - rebulacia, inpjegat, pasađ, partili, tratamenti, kanbial, fermati, frute, đandari, adobati, angoizam. 
Njirićevi zapisi zanimljivi su i iz perspektive samoidentifikacije autora u nacionalnom i regionalnom smislu. Ovisno o kontekstu i sugovornicima, Njirić se identificira kao Austrianc iz Dalmacije, Dalmatinac od Dubrovnika ili pak, kad se raspituje o sunarodnjacima u Čileu, kao Austriako, dok materinski jezik naziva naški. Premda su migrantski život i odnos s obitelji dvije glavne niti Njirićeva pripovijedanja, on spominje i događaje koji su obilježili političku situaciju u zemljama kroz koje je prolazio ili u njima duže boravio, kao što su primjerice revolucije u Argentini i Čileu, »Veliki rat« u Europi, propast Austro-Ugarske ili nastanak Jugoslavije.

Vjerojatno glavni povod Njirićeva pisanja leži u njegovim složenim odnosima s roditeljima i braćom, osobito u kontekstu zasnivanja vlastite obitelji. O njegovoj potrebi da svoje životne dogodovštine i nedaće podijeli s čitateljima svjedoči rečenica iz zadnjeg dijela teksta: »Rada bi naći jednu krštenu osobu kojom bi mogao predati ovu istoriju, da je pročita od moga dezgraciana života.« U njegovu slučaju nije samo posrijedi zadovoljenje ispovjedne potrebe i nalaženja razumijevanja kod nepoznatih čitatelja (kad to već nije pronašao u krugu najbližih), što je naglasio riječima »Ali se nadam da će se naći više nego jedna koja će me zažaliti i reći mi da fala Bogu i kad umrem da mi Bog do raj«, već se nazire i određena didaktička funkcija. Pouku koju bi nepristrani čitatelj trebao izvući iz njegove »istorije« izražava Njirić u zaključnim rečenicama izgovarajući neku vrstu narodne mudrosti: »Dok si imo bilo dobro. (...) A kada ništa nemaš ništa i ne valjaš, niko te ne pita jesi li dobar, jesi li pošten, nego samo koliko imaš. Propo liberalizam, osto agojizam.«

Autobiografskih zapisa pripadnika Njirićeva društvenog sloja s prijelaza iz 19. u 20. stoljeće razmjerno je malo, a na hrvatskom jeziku gotovo da ih i nema. Drugim riječima, rijetka su svjedočanstva običnih ljudi i iseljenika koji nisu stekli »bogatstvo i slavu« $\mathrm{i}$ koji su ostali nepoznati u javnosti, za razliku od nekih drugih iseljenika s kraja 19. stoljeća - Ivana Vučetića, Jakova Buratovića, Ivana Benigara, braće Nikole i Miha Mihanovića i Ivana Jagšića, da spomenemo samo nekolicinu onih koji su se istaknuli svojim poduzetničkim ili istraživačkim uspjesima, iako većina njih nije ostavila pisanih tragova o svom životu. Njirićev je tekst zanimljiv i istraživačima i običnim čitateljima jer pruža uvid u način razmišljanja »malog čovjeka«, čija je sudbina tipična sudbina hrvatskog iseljenika toga razdoblja u potrazi za boljim životom i ekonomskom sigurnošću. Pritom valja naglasiti da mnogi od tih iseljenika nisu postigli ni materijalnu sigurnost, a o društvenom uspjehu i slavi da i ne govorimo. Brojniji su iseljenički zapisi osobne prirode iz razdoblja nakon Drugoga svjetskog rata. Neki su od njih objavljeni, poput knjige 
Stjepana Lojena Uspomene jednog iseljenika (1963.), knjige Luke Markovića Pod australskim nebom (1973.) ili knjige Vande Boras Podravec Dnevnik iz tuđine (2011.), pružajući također uvid u iseljeničko iskustvo, osobne biografije i obiteljske prilike te se osvrćući na razloge (ekonomske ili političke) svog odlaska u prekomorske zemlje. Takvi tekstovi, obično napisani nakon iseljeničkog iskustva, nisu samo osobne ispovijedi o teško proživljenom životu, nego često nose i snažnu političku poruku.

Iako svoj autobiografski zapis Vicko Njirić započinje podatkom o danu i načinu odlaska iz rodnoga kraja, bez ikakva objašnjenja razloga odlaska, iz njegova je pripovijedanja jasno da su ti razlozi bili ekonomske naravi. Pripovjedač očito nije imao potrebu obrazlagati ih jer su bili očigledni i tipični za većinu hrvatskih krajeva na prijelazu iz 19. u 20. stoljeće. O tome svjedoči činjenica, koju ističe na više mjesta u svojem tekstu, da su iseljeni Hrvati jedni drugima u tuđini bili oslonac, i to ne samo u ekonomskom već i u emocionalnom smislu.

Čitatelj koji autobiografski zapis Vicka Njirića - Puhe uzme u ruke bez prevelikog očekivanja, bit će ugodno iznenađen njegovom iskrenošću, neposrednošću i bogatstvom detalja. Zanimljivosti teksta pridonose kako sama životna priča Vicka Njirića tako i jezik kojim je ispričana.

\section{LITERATURA}

Brändle, F., von Greyerz, K., Heiligensetzer, L., Leutert, S. i Piller, G. (2001). Texte zwischen Erfahrung und Diskurs. Probleme der Selbstzeugnisforschung, u: K. von Greyerz, H. Medick i P. Veit (ur.). Von der dargestellten Person zum erinnerten Ich: Europäische Selbstzeugnisse als historische Quellen (1500-1850). Köln: Böhlau, 3-31.

van Dülmen, R. (2005). Otkriće individuuma 1500.-1800. Zagreb: Golden marketing Tehnička knjiga.

Duvnjak Radić, Ž. (2011). Autobiografija, fikcija i ja: problem fikcionalnosti autobiografske proze. Beograd: Službeni glasnik.

Engelbrecht, J. (1992). Autobiographien, Memoiren, u: B.-A. Rusinek, V. Ackermann i J. Engelbrecht (ur.). Einführung in die Interpretation historischer Quellen. SchwerpunktNeuzeit. Paderborn - München - Wien - Zürich: Schöningh, 61-79.

Montaigne, M. de (2007). Dnevnik s puta u Italiju preko Švicarske i Njemačke 1580. i 1581. Pisma. Zagreb: Disput, 2007.

Njirić, V.- Puho (2017). Tužna povijes moga života: dnevnički zapisi. Dubrovnik: Matica hrvatska - Ogranak u Dubrovniku.

Wisthaler, S. (2011). Karl Außerhofer - Das Kriegstagebuch eines Soldaten im Ersten Weltkrieg, u: Alpine Space - Man E Environment, vol. 8. Innsbruck: Innsbruck University Press.

Zlatar, A. (2000). Ispovijest $i$ životopis: srednjovjekovna autobiografija: rasprava. Zagreb: Antibarbarus. 
